\title{
Synthesis and Properties of Polyguanamines from 2,4-Dichloro-6-phenyl-1,3,5-triazine and Diamine
}

\author{
Yasuo YukI ${ }^{\dagger}$ Hideo Kunisada, Kazuhiro IIDA, and Shuji Kondo \\ Department of Materials Science and Engineering, Nagoya Institute of Technology, \\ Gokiso-cho, Showa-ku, Nagoya 466, Japan
}

(Received November 21, 1995)

\begin{abstract}
KEY WORDS Guanamine / Polyguanamine / 1,3,5-Triazine / Dichlorotriazine / Polycondensation / Phase Transfer Catalyst
\end{abstract}

Recently, we reported the synthesis of polyguanamines (2c) by alkylation reaction of 2,4-dianilino-6-phenyl1,3,5-triazine with 1,6-dibromohexane in the presence of sodium hydride (Scheme 1). ${ }^{1}$ The resulting polyguanamine can be use as an effective phase transfer catalyst for reactions of 1-bromooctane with potassium thiocyanate in toluene-water systems.

It is well known that chlorine atoms attached directly

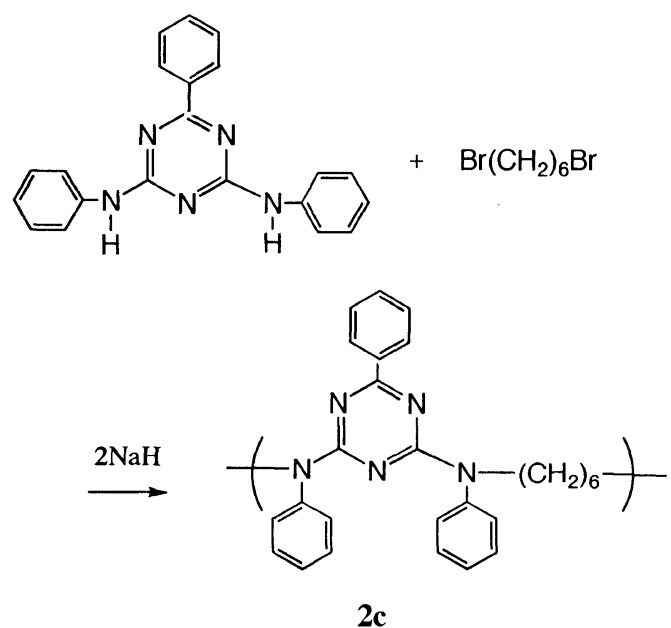

Scheme 1.<smiles>[X]NCCNCCN[X]</smiles>

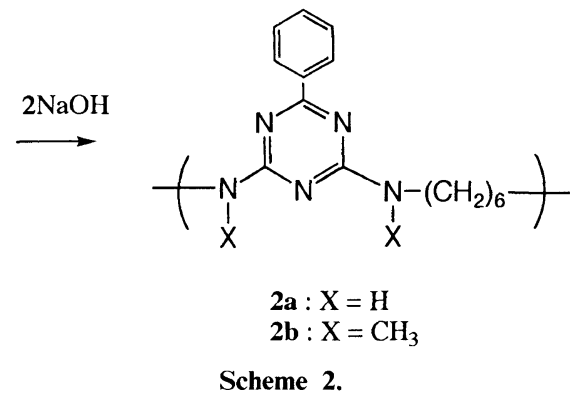

* To whom all correspondence should be addressed. to the 1,3,5-triazine ring are very reactive and can be displaced readily by nucleophilic reagents such as amines, ${ }^{2}$ alkoxides, ${ }^{3,4}$ and mercaptides. ${ }^{5}$ It has been reported that reactions of dichlorotriazines with diols, ${ }^{6-8}$ diamines,,$^{9-11}$ or guanamines ${ }^{12-14}$ give the corresponding polymers.

This paper describes the polycondensation of 2,4dichloro-6-phenyl-1,3,5-triazine with hexamethylenediamine and $N, N^{\prime}$-dimethylhexamethylenediamine for the synthesis of analogous polyguanamines to 2c (Scheme 2 ). The effects of $N$-substituents on thermal properties and ability to act as polymeric phase transfer catalysts of the resulting polyguanamines ( $\mathbf{2} \mathbf{a}$ and $\mathbf{2 b}$ ) were also investigated.

\section{EXPERIMENTAL}

\section{Materials}

2,4-Dihydroxy-6-phenyl-1,3,5-triazine was prepared by hydrolysis reaction of $46.5 \mathrm{~g}(0.25 \mathrm{~mol})$ of benzoguanamine in $150 \mathrm{~g}$ of $90 \mathrm{wt} \%$ sulfuric acid at $120^{\circ} \mathrm{C}$ for $15 \mathrm{~h}$. The reaction mixture was poured into water to give a white solid, which was filtered off, washed with water, and dried. Yield $35.9 \mathrm{~g}(82.0 \%)$, mp $288^{\circ} \mathrm{C}$ (lit. ${ }^{15} 289$ $290^{\circ} \mathrm{C}$, decomp.).

\section{Monomer Synthesis}

2,4-Dichloro-6-phenyl-1,3,5-triazine (1) was prepared by reaction of $36.2 \mathrm{~g}(0.21 \mathrm{~mol})$ of 2,4 -dihydroxy-6phenyl-1,3,5-triazine with $180 \mathrm{~g}(1.51 \mathrm{~mol})$ of thionyl chloride and $17.3 \mathrm{~g}$ of $N, N$-dimethylformamide (DMF) at $60^{\circ} \mathrm{C}$ for $3 \mathrm{~h}$. The excess thionyl chloride was distilled, and the residue was poured into water to give a product. The white product was filtered off, dried, and recrystallized from benzene to give a yield of $22.0 \mathrm{~g}(47.4 \%)$. mp $118^{\circ} \mathrm{C}$ (lit. $\left.121^{\circ} \mathrm{C}^{16} 118-119^{\circ} \mathrm{C}^{17}\right) .{ }^{1} \mathrm{H}$ NMR $(\delta \mathrm{ppm}$ in $\left.\mathrm{CDCl}_{3}\right) ; 7.50(2 \mathrm{H}, \mathrm{d}, m-\mathrm{H}), 7.64(1 \mathrm{H}, \mathrm{t}, p-\mathrm{H}), 8.44$ $(2 \mathrm{H}, \mathrm{d}, o-\mathrm{H})$. Anal. Calcd for $\mathrm{C}_{9} \mathrm{H}_{5} \mathrm{~N}_{3} \mathrm{Cl}_{2}$ : C, $48.24 \%$; H, 2.25\%; N, 18.75\%. Found: C, $48.32 \% ; H, 2.10 \%$; $18.53 \%$.

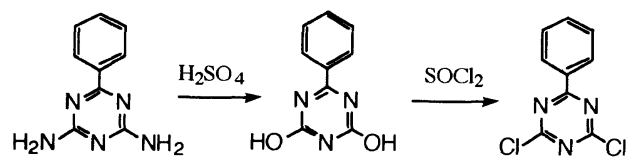


Reaction of 1 with Hexamethylenediamine

$1(2.24 \mathrm{~g}, 10.0 \mathrm{mmol})$ and hexamethylenediamine dihydrochloride $(1.89 \mathrm{~g}, 10.0 \mathrm{mmol})$ were added to tetrahydrofuran (THF) $(60 \mathrm{ml})$ and $8 \mathrm{~N}$ sodium hydroxide aq $(7 \mathrm{ml})$ with stirring. The reaction mixture was stirred for $8 \mathrm{~h}$ at room temperature. A small amount of insoluble compound in THF (3a) was filtered off to yield $0.10 \mathrm{~g}$ $(3.8 \%)$. The filtrate was poured into methanol to give polyguanamine $\mathbf{2 a}$. The isolated $\mathbf{2 a}$ was washed with methanol, reprecipitated from THF into diethyl ether, and dried in vacuo to give a yield of $2.23 \mathrm{~g}(82.9 \%) . \mathbf{2 a}$ : $T_{\mathrm{g}} 95^{\circ} \mathrm{C}$. IR (KBr) 3420, 3260, 2920, 2850, 1590, 1540, 1410, 1370, 1220,820,780, $700 \mathrm{~cm}^{-1}$. Anal. Calcd for $\mathrm{C}_{15} \mathrm{H}_{19} \mathrm{~N}_{5}$ : C, 66.89\%; H, 7.11\%; N, 26.00\%. Found: C, $66.07 \%$; H, 7.17\%; N, 25.76\%. 3a: mp $268^{\circ} \mathrm{C}$. MS $m / z$ 187.0, 269.1 ( $\mathbf{M}^{+}$, Calcd 269.4). Anal. Calcd for $\mathrm{C}_{15} \mathrm{H}_{19} \mathrm{~N}_{5}$ : C, 66.89\%; H, 7.11\%; N, 26.00\%. Found: C, $66.84 \% ; \mathrm{H}, 7.25 \%$; N, $25.80 \%$.

Reaction of 1 with $N, N^{\prime}$-Dimethylhexamethylenediamine

$1(2.24 \mathrm{~g}, 10.0 \mathrm{mmol})$ and $N, N^{\prime}$-dimethylhexamethylenediamine $(1.47 \mathrm{~g}, 10.0 \mathrm{mmol})$ were added to THF $(25 \mathrm{ml})$ and $4 N$ sodium hydroxide aq $(6 \mathrm{ml})$ with stirring, and the reaction mixture was stirred for $24 \mathrm{~h}$ at room temperature. A small amount of insoluble compound in THF (3b) was filtered off in the amount of $0.23 \mathrm{~g}$ $(7.7 \%)$. The filtrate was poured into methanol to give polyguanamine $\mathbf{2 b}$. The isolated $\mathbf{2 b}$ was washed with methanol, reprecipitated from $\mathrm{THF}$ into hexane, and dried in vacuo in a yield of $2.48 \mathrm{~g}(83.5 \%)$.

2b: $T_{\mathrm{g}} 57^{\circ} \mathrm{C}$. IR (KBr) 2920, 2850, 1590, 1540, 1500, 1390, 1310, 1200, 1050, 975, 810,780,700,650 $\mathrm{cm}^{-1}$. Anal. Calcd for $\mathrm{C}_{17} \mathrm{H}_{23} \mathrm{~N}_{5}: \mathrm{C}, 68.66 \% ; \mathrm{H}, 7.79 \%$; , $23.55 \%$. Found: C, 68.34\%; H, 7.77\%; N, 23.55\%.

3b: $\mathrm{mp} 240^{\circ} \mathrm{C}$. MS $m / z 215.0,229.2,243.1,256.1$, 270.2, 284.0, 298.1 (M ${ }^{+}$, Calcd 297.4). Anal. Calcd for $\mathrm{C}_{17} \mathrm{H}_{23} \mathrm{~N}_{5}$ : C, $68.66 \% ; \mathrm{H}, 7.79 \% ; \mathrm{N}, 23.55 \%$. Found: C, $68.70 \% ; \mathrm{H}, 7.92 \%$; N, 23.30\%.
Catalytic Activity for Substitution Reactions

Catalytic activity of polyguanamines was assessed in two-phase reactions of 1-bromooctane with potassium thiocyanate, as described previously. ${ }^{1}$

\section{RESULTS AND DISCUSSION}

\section{Synthesis of Polyguanamines}

Polyguanamines $\mathbf{2 a}$ and $\mathbf{2 b}$ were prepared by the polycondensation of $\mathbf{1}$ with hexamethylenediamine and $N, N^{\prime}$-dimethylhexamethylenediamine in the presence of sodium hydroxide, respectively. A small amount of insoluble compound in THF (3a and $\mathbf{3 b}$ ) was obtained as impurity. The results of analysis of polymers agreed well with calculated values. IR spectra showed characteristic $\mathrm{CH}_{2}$ stretching band at 2920 and $2850 \mathrm{~cm}^{-1}$, in addition to usual absorption bands of 1,3,5-triazine which appeared at 1540, 1410-1390, and 820-810 $\mathrm{cm}^{-1}$. The characteristic $\mathrm{N}-\mathrm{H}$ stretching band at $3260 \mathrm{~cm}^{-1}$ was observed for $\mathbf{2 a}$. Chemical shifts of $\mathbf{2 a}$, $\mathbf{2 b}, \mathbf{3 a}$, and $\mathbf{3 b}$ are summarized in Table I. The NMR spectrum of $\mathbf{2 b}$ measured in chloroform- $d$ at room temperature shows the signal of $\mathrm{N}-\mathrm{CH}_{3}$ as two peaks at 3.10 and $3.20 \mathrm{ppm}$, and $\mathrm{N}-\mathrm{CH}_{2}$ at 3.60 and $3.72 \mathrm{ppm}$ at about $1: 1$ strength, respectively. But at $50^{\circ} \mathrm{C}$ the signal of $\mathrm{N}-\mathrm{CH}_{3}$ became one peak at $3.15 \mathrm{ppm}$, and that of $\mathrm{N}-\mathrm{CH}_{2}$ at $3.66 \mathrm{ppm}$. The reason for this may be that the $\mathrm{C}-\mathrm{N}$ bond between triazine and amino group has the property of double bond and free rotation is restricted.

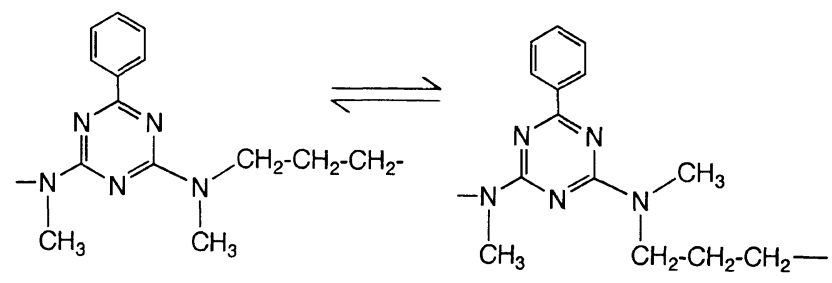

Table I. ${ }^{1} \mathrm{H}$ NMR of $\mathbf{2 a}, \mathbf{2 b}, \mathbf{3 a}$, and $\mathbf{3 b} \delta \mathrm{ppm}$

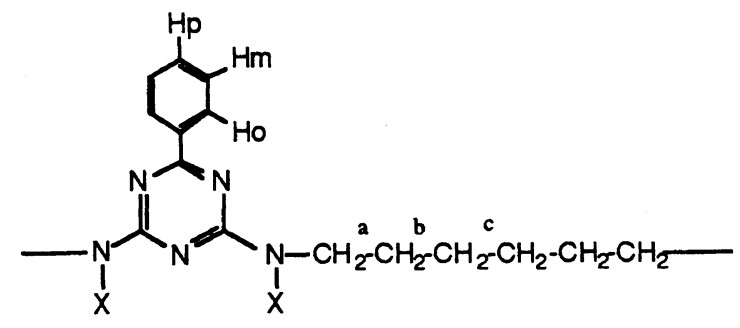

\begin{tabular}{|c|c|c|c|c|c|c|c|c|c|}
\hline Compd. & Solvent & $\mathrm{Temp} /{ }^{\circ} \mathrm{C}$ & $H_{\mathrm{o}}$ & $H_{\mathrm{m}}$ & $H_{\mathrm{p}}$ & $X$ & $H_{\mathrm{a}}$ & $H_{\mathrm{b}}$ & $H_{\mathrm{c}}$ \\
\hline \multirow[t]{2}{*}{$2 a$} & $\left(\mathrm{CD}_{3}\right)_{2} \mathrm{SO}$ & 60 & $\begin{array}{c}8.32 \\
(2 \mathrm{H}, \text { br s })\end{array}$ & \multicolumn{2}{|c|}{$\begin{array}{c}7.47 \\
(3 \mathrm{H}, \mathrm{brs})\end{array}$} & $\begin{array}{c}7.02 \\
(2 \mathrm{H}, \mathrm{s})\end{array}$ & $\begin{array}{c}3.34 \\
(4 \mathrm{H}, \text { br s })\end{array}$ & $\begin{array}{c}1.56 \\
(4 \mathrm{H}, \mathrm{brs})\end{array}$ & $\begin{array}{c}1.35 \\
(4 \mathrm{H}, \text { br s })\end{array}$ \\
\hline & $\mathrm{CF}_{3} \mathrm{COOD}$ & r.t. & $\begin{array}{c}7.98 \\
(2 \mathrm{H}, \mathrm{d})\end{array}$ & $\begin{array}{c}7.72 \\
(2 \mathrm{H}, \mathrm{t})\end{array}$ & $\begin{array}{c}7.89 \\
(1 \mathrm{H}, \mathrm{t})\end{array}$ & - & $\begin{array}{c}3.78 \\
(4 \mathrm{H}, \mathrm{t})\end{array}$ & $\begin{array}{c}1.86 \\
(4 \mathrm{H}, \mathrm{brs})\end{array}$ & $\begin{array}{c}1.60 \\
(4 \mathrm{H}, \text { br s })\end{array}$ \\
\hline \multirow[t]{3}{*}{$2 \mathbf{b}$} & $\mathrm{CDCl}_{3}$ & r.t. & $\begin{array}{c}8.45 \\
(2 \mathrm{H}, \mathrm{brs})\end{array}$ & \multicolumn{2}{|c|}{$\begin{array}{c}7.43 \\
(3 \mathrm{H}, \mathrm{brs})\end{array}$} & $\begin{array}{c}3.10,3.20 \\
(3 \mathrm{H}+3 \mathrm{H}, \text { brs })\end{array}$ & $\begin{array}{c}3.60,3.72 \\
(2 \mathrm{H}+2 \mathrm{H}, \text { brs })\end{array}$ & $\begin{array}{c}1.65 \\
(4 \mathrm{H}, \mathrm{brs})\end{array}$ & $\begin{array}{c}1.40 \\
(4 \mathrm{H}, \text { br s })\end{array}$ \\
\hline & $\mathrm{CDCl}_{3}$ & 50 & $\begin{array}{c}8.45 \\
(2 \mathrm{H}, \text { brs })\end{array}$ & \multicolumn{2}{|c|}{$\begin{array}{c}7.43 \\
(3 \mathrm{H}, \mathrm{brs})\end{array}$} & $\begin{array}{c}3.15 \\
(6 \mathrm{H}, \mathrm{s})\end{array}$ & $\begin{array}{c}3.66 \\
(4 \mathrm{H}, \mathrm{brs})\end{array}$ & $\begin{array}{c}1.65 \\
(4 \mathrm{H}, \mathrm{brs})\end{array}$ & $\begin{array}{c}1.40 \\
(4 \mathrm{H}, \text { br s })\end{array}$ \\
\hline & $\mathrm{CF}_{3} \mathrm{COOD}$ & r.t. & $\begin{array}{c}8.06 \\
(2 \mathrm{H}, \mathrm{d})\end{array}$ & $\begin{array}{c}7.69 \\
(2 \mathrm{H}, \mathrm{t})\end{array}$ & $\begin{array}{c}7.80 \\
(1 \mathrm{H}, \mathrm{t})\end{array}$ & $\begin{array}{c}3.47 \\
(6 \mathrm{H}, \mathrm{s})\end{array}$ & $\begin{array}{c}3.81 \\
(4 \mathrm{H}, \mathrm{brs})\end{array}$ & $\begin{array}{c}1.88 \\
(4 \mathrm{H}, \mathrm{brs})\end{array}$ & $\begin{array}{c}1.57 \\
(4 \mathrm{H}, \text { br s })\end{array}$ \\
\hline $\mathbf{3 a}$ & $\mathrm{CF}_{3} \mathrm{COOD}$ & r.t. & $\begin{array}{c}7.98 \\
(2 \mathrm{H}, \mathrm{d})\end{array}$ & $\begin{array}{c}7.72 \\
(2 \mathrm{H}, \mathrm{t})\end{array}$ & $\begin{array}{c}7.91 \\
(1 \mathrm{H}, \mathrm{t})\end{array}$ & - & $\begin{array}{c}3.74 \\
(4 \mathrm{H}, \mathrm{t})\end{array}$ & $\begin{array}{c}1.88 \\
(4 \mathrm{H}, \mathrm{brs})\end{array}$ & $\begin{array}{c}1.59 \\
(4 \mathrm{H}, \mathrm{brs})\end{array}$ \\
\hline $\mathbf{3 b}$ & $\mathrm{CF}_{3} \mathrm{COOD}$ & r.t. & $\begin{array}{c}8.06 \\
(2 \mathrm{H}, \mathrm{d})\end{array}$ & $\begin{array}{c}7.64 \\
(2 \mathrm{H}, \mathrm{t})\end{array}$ & $\begin{array}{c}7.80 \\
(1 \mathrm{H}, \mathrm{t})\end{array}$ & $\begin{array}{c}3.47 \\
(6 \mathrm{H}, \mathrm{s})\end{array}$ & $\begin{array}{c}3.81 \\
(4 \mathrm{H}, \mathrm{brs})\end{array}$ & $\begin{array}{c}1.88 \\
(4 \mathrm{H}, \mathrm{brs})\end{array}$ & $\begin{array}{c}1.57 \\
(4 \mathrm{H}, \text { br s })\end{array}$ \\
\hline
\end{tabular}


The spectra of polyguanamines shifted to lower field in trifluoroacetic acid- $d$ than in DMSO or chloroform- $d$, because the protonation to triazine ring occurs in trifluoroacetic acid.

The solubility of polymers was examined. All polyguanamines $(\mathbf{2 a - 2 c )}$ are soluble in THF, $N$-methyl-2pyrrolidone, $N, N$-dimethylacetamide, and acidic solvents such as formic acid and sulfuric acid, but insoluble in acetone, alcohol, and hexane. $\mathbf{2 b}$ and $\mathbf{2 c}$ are soluble in dioxane, benzene, and chloroform, but $\mathbf{2 a}$ is insoluble. 2a is soluble in dimethyl sulfoxide (DMSO), but $\mathbf{2 b}$ and $\mathbf{2 c}$ are insoluble. The inherent viscosities $\left(\eta_{\mathrm{sp}} / c\right)$ of $\mathbf{2 a}$ and $\mathbf{2 b}$ measured at $c=0.2 \mathrm{~g} \mathrm{dl}^{-1}$ in THF at $30^{\circ} \mathrm{C}$ were 0.18 and $0.19 \mathrm{dlg}^{-1}$, respectively. Molecular weights were estimated as $\bar{M}_{n}=9.600\left(\bar{M}_{w} / \bar{M}_{n}=1.9\right)$ for $\mathbf{2 a}$ and 10.500 $\left(\bar{M}_{w} / \bar{M}_{n}=2.3\right)$ for $\mathbf{2 b}$ by GPC measurement in THF using polystyrene as the standard.

Glass transition temperatures $\left(T_{\mathrm{g}}\right)$ of $\mathbf{2 a}, \mathbf{2} \mathbf{b}$, and $\mathbf{2 c}$ evaluated by DSC measurements at a heating rate of $20^{\circ} \mathrm{C} \mathrm{min}^{-1}$ were $95^{\circ} \mathrm{C}, 57^{\circ} \mathrm{C}$, and $74^{\circ} \mathrm{C}$, respectively. $T_{\mathrm{g}}$ decreases in the following order; $\mathbf{2} \mathbf{a}>\mathbf{2} \mathbf{c}>\mathbf{2 b}$ since $\mathbf{2} \mathbf{a}$ forms hydrogen bonds. The temperature for $10 \%$ weight loss $\left(T_{10}\right)$ was determined by TGA measurement at a heating rate of $10^{\circ} \mathrm{Cmin}^{-1} . T_{10} \mathrm{~s}$ of $2 \mathbf{a}, 2 \mathbf{b}$, and $2 \mathbf{c}$ were $422^{\circ} \mathrm{C}, 377^{\circ} \mathrm{C}$, and $428^{\circ} \mathrm{C}$, respectively.

\section{Formation of $\mathbf{3 a}$ and $\mathbf{3 b}$}

3a and 3b showed high melting points and insolubility in common organic solvents. Their structures were identified by elementary analysis, IR, ${ }^{1} \mathrm{H}$ NMR, and mass spectroscopy. The results of analysis agreed well with calculated values of the corresponding polymers. Their NMR spectra in trifluoroacetic acid- $d$ and IR spectra are similar to those of the corresponding polymers (Table I). The parent peaks of mass spectra of 3a and $\mathbf{3 b}$ agreed with the $1: 1$ condensation products. These results show that $\mathbf{3 a}$ and $\mathbf{3 b}$ may be analogous cyclization compounds obtained from 2,4-dianilino-6substituted-1,3,5-triazine with $\alpha, \omega$-dibromoalkane previously. ${ }^{1}$

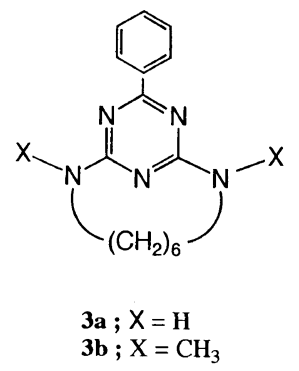

\section{Catalytic Activity for Substitution Reactions}

The catalytic activity of polyguanamines was assessed for reactions of 1-bromooctane in toluene with potassium thiocyanate in water under two-phase (2b and $\mathbf{2} \mathbf{c})$ or three-phase ( $\mathbf{2} \mathbf{a})$ conditions. The results are summarized in Table II.

$$
n-\mathrm{C}_{8} \mathrm{H}_{17} \mathrm{Br}+\mathrm{KSCN} \stackrel{\text { Catalyst }}{\longrightarrow} n-\mathrm{C}_{8} \mathrm{H}_{17} \mathrm{SCN}+\mathrm{KBr}
$$

The reaction was achieved in the presence of mono-
Table II. Yields of octylthiocyanate of the reaction of 1-bromooctane with potassium thiocyanate under toluene/water condition using polyguanamines as a phase-transfer catalyst

\begin{tabular}{lc}
\hline Catalyst & \multicolumn{1}{c}{ Yield $^{\mathbf{a}}$} \\
\cline { 2 - 2 } & $\%$ \\
\hline BG $^{\mathbf{b}}$ & 47 \\
$\mathrm{TMBG}^{\mathbf{c}}$ & 46 \\
$\mathbf{2 a}$ & 97 \\
$\mathbf{2 b}$ & 97 \\
$\mathbf{2 c}$ & 96
\end{tabular}

${ }^{a}$ Conditions: 1 -bromooctane $=1.65 \mathrm{mmol}$ in $1 \mathrm{ml}$ toluene; potassium thiocyanate $=8.0 \mathrm{moll}^{-1}$ (in water), $5 \mathrm{ml}$; and catalyst $=0.3 \mathrm{mmol}$ at $100^{\circ} \mathrm{C}$ for $30 \mathrm{~h}$ under stirring. ${ }^{\mathrm{b}}$ Benzoguanamine. $\quad{ }^{\mathrm{c}} N, N, N^{\prime}, N^{\prime}$ Tetramethylbenzoguanamine.

meric analogs (benzoguanamine and $N, N, N^{\prime}, N^{\prime}$-tetramethylbenzoguanamine) and polyguanamines. Monomeric analogs gave octyl thiocyanate in $46-47 \%$ yield and polymers gave the product in above $90 \%$ yield. The catalytic activity of polymers is superior to that of monomeric analogs. These observations may be explained by assuming that potassium cations interact with several active sites to form a complex, and thiocyanate anions attack the substrate. This cooperative coordination of active sites may occur readily in polymers. ${ }^{1,18}$

\section{REFERENCES}

1. Y. Yuki, H. Kunisada, K. Iida, T. Fukaya, and S. Kondo, Polym. J., 28, 337 (1996).

2. T. T. Thurston, J. R. Dudley, D. W. Kaiser, I. Hechenbleikner, F. C. Schaefer, and D. Holm-Hansen, J. Am. Chem. Soc., 73, 2981 (1951).

3. J. R. Dudley, J. T. Thurston, F. C. Schaefer, D. Holm-Hansen, C. J. Hull, and P. Adams, J. Am. Chem. Soc., 73, 2986 (1951).

4. J. T. Thurston, F. C. Schaefer, and J. R. Dudley, J. Am. Chem. Soc., 73, 2990 (1951)

5. S. Kondo, T. Yamamoto, H. Kunisada, and Y. Yuki, J. Macromol. Sci. Chem., A27, 1515 (1990).

6. L. G. Picklesimer and T. L. Saunders, J. Polym. Sci., Part A, 3, $2673(1965)$

7. K. Seta, K. Tamura, Y. Saito, and Y. Nakamura, Kogyo Kagaku Zasshi, 70, 588, 2066 (1967).

8. R. Audebert and J. Neel, J. Polym. Sci., Part C, 16, 3245 (1968).

9. J. Sundquist and H. Heinz, Angew Makromol. Chem., 14, 203 (1970).

10. D. W. Wang and M. M. Fisher, J. Polym. Sci., Polym. Chem. Ed., 21, 671 (1983).

11. J. A. Mikroyannidis, J. Polym. Sci., Polym. Chem. Ed., 26, 583 (1988).

12. H. K. Reimschuessel, A. M. Lovelace, and E. M. Hagerman, J. Polym. Sci., 40, 270 (1959).

13. G. F. L. Ehlers and J. D. Ray, J. Polym. Sci., Part A, 2, 4989 (1964).

14. G. F. L. Ehlers and J. D. Ray, J. Polym. Sci., Part A, 4, 1645 (1966).

15. CIBA Ltd., Belg. 634,399 [Chem. Abstr., 61, 671d (1964)].

16. H. Albers, R. Oster, and H. Schroedar, Ger. 1,178,052 [Chem. Abstr., 61, 16080g (1964)].

17. H. G. Schmelzer and E. Degener, Ger. 1,178,437 [Chem. Abstr., 61, 16081d (1964)].

18. Y. Yuki, H. Kunisada, K. Iida, and S. Kondo, Polym. J., 27, 1239 (1995). 